\title{
The Potential of Use Lavender from Vegetable Waste as Effective Antibacterial and Sedative Agents
}

\author{
Michalina Adaszyńska-Skwirzyńska ${ }^{1}$, Maria Swarcewicz ${ }^{*}$ and Agnieszka Dobrowolska² \\ 1 Institute of Organic Chemical Technology, Department of Organic Synthesis and Drug Technology, the West Pomeranian University of Technology, Aleja Piastow 42, 71 \\ 065 Szczecin, Poland \\ ${ }^{2}$ The West Pomeranian University of Technology, Faculty of Environment Management and Agriculture, 3A Pawla VI Street, 71-459 Szczecin, Poland
}

\begin{abstract}
Only the flowers of lavender (Lavandula angustifolia) are utilized for the medical purposes. The aim of the current study was to compare the chemical composition, concentrations of flavonoids and sesquiterpene acids in the leafy stems in two varieties of lavender oils the 'Blue River' (BR) and the 'Ellegance Purple' (EP). Their biological activity against four pathogenic bacteria Staphylococcus aureus, Pseudomonas aeruginosa, Escherichia coli and Enterococcus faecalis was study. The main constituents were borneol (13.8-12.4\%), and caryophyllene oxide (8.0$8.7 \%$ ). Total flavonoids content were similar in both plants, from 341 to $352 \mathrm{mg} / 100 \mathrm{~g}$. The valerenic acid was from 1.08 to $0.81 \mathrm{mg} / 100 \mathrm{~g}$ in BR and EP, respectively. The acetoxyvalerenic acid was from 45.9 to $14.0 \mathrm{mg} / 100 \mathrm{~g}$, respectively. The highest increase of $S$. aureus bacteria was inhibited by the activity of the essential oils from both varieties. The less effect of inhibition was noticed for Escherichia coli for both plants.
\end{abstract}

Keywords: Lavandula angustifolia; Vegetable waste; Constituent; Flavonoids; Sesquiterpene acids; Pathogenic bacteria

\section{Introduction}

Essential oils from members of the genus Lavandula with the most commonly used species being L. angustifolia, L. latifolia, L. stoechas and L. $\mathrm{x}$ intermedia have been used in pharmaceutical, cosmetic and food industries [1-3]. Major chemical constituents are similar between various lavenders, some differences do occur in both oil composition and in the reported therapeutic uses for different species [2]. Only the flowers of lavender (Lavandula angustifolia) are utilized for the medical purposes. Previously study with lavender oil from flowers showed antibacterial and antifungal properties [1,2]. Lavender oil has been found to be active against many species of bacteria, including those resistant to antibiotics such as methicillin-resistant Staphylococcus aureus (MRSA) and vancomycin-resistant Enterococcus (VRE). Moon et al. [3] showed good antibacterial activity of lavender against a range of bacteria including Streptococcus pyogenes, Enterobacter aerogenes, S. aureus, MRSA, Pseudomonas aeruginosa, Citrobacter freundii, Proteus vulgaris, Escherichia coli, VRE, Shigella sonnei and Propionibacterium acnes.

It was found that sedative of vegetable plant material on the central nervous system is a result action of a mixture of substances. Essential oil from lavender flowers, sesquiterpene acids may plays an important role on the central nervous system $[4,5]$. Result of study showed that a calming and sedative effect, reduction of stress and mood improvement answer can be one of the components of lavender, linalool and sesquiterpene acids [6]. Clinical studies have shown that the inhalation added after oral ingestion or infusion of lavender flowers has the positive effect [6]. Lavender works to stimulate the case of mental heaviness. The positive impact of lavender essential oil was also observed in the case of migraines and motion sickness commonly associated with the stress of travel and associated vertigo neurotic origin shown that lavender has antidepressant action [4-7].

The composition of the essential oils from different aerial parts of Lavandula coronopofolia Poiert (syn. Stricta delile L.) (Lamiaceae) were showed by Aburjai et al. [8]. Also, essential oils from the stems/leaves (L) and flowers (F) of Lavandula stoechas L. ssp. stoechas growing wild in Italy were study $[9,10]$.

Lavender oil from flowers due to its high price is often diluted by cheaper oils, as well as synthetic products, such as linalyl acetate
[1]. This was the reason for undertaking research into the use of the lavender waste. The aim of this study was to investigate the chemical composition of the waste material from the production of lavender essential oil. Attempts have been made to isolate the essential oil, sesquiterpene acids and flavonoids from the leafy stems of two varieties of lavender (Lavandula angustifolia) the 'Blue River' (BR) and the 'Ellegance Purple' (EP) which growing in Poland. We investigated also the effect of biological activity of oil from vegetable waste against four pathogenic bacteria Staphylococcus aureus, Pseudomonas aeruginosa, Escherichia coli and Enterococcus faecalis. We compared the results with previously data of essential oils from lavender flowers [11].

\section{Materials and Methods}

\section{Plant material and isolation of the essential oil}

The material was taken from the leafy stems of two varieties of lavender (Lavandula angustifolia): 'Blue River' (BR) and 'Ellegance Purple' (EP). Plants derived from experimental cultivation Horticulture Department West Pomeranian University of Technology in Szczecin from the set in July 2012. The plant samples were identified at the Department of Horticulture, Faculty of Environment Management and Agriculture of West Pomeranian University of Technology in Szczecin on the basis of voucher specimen from Institute of Natural Fibres and Medicinal Plants, Poznan, Poland. In order to isolate the essential oil of lavender leafy stems of two varieties, the amount of $20 \mathrm{~g}$ was subjected to a three hours of hydro distillation in the Deryng's apparatus according to the European Pharmacopoeia [12-27].

*Corresponding author: Maria Swarcewicz, Institute of Organic Chemical Technology, Department of Organic Synthesis and Drug Technology, the West Pomeranian University of Technology, Aleja Piastow 42, 71-065 Szczecin, Poland Tel: +48 9144947 41; Fax: +48 9144943 65; E-mail: madaszynska@zut.edu.pl

Received July 03, 2014; Accepted October 25, 2014; Published October 27 2014

Citation: Adaszyńska-Skwirzyńska M, Swarcewicz M, Dobrowolska A (2014) The Potential of Use Lavender from Vegetable Waste as Effective Antibacterial and Sedative Agents. Med chem 4: 734-737. doi:10.4172/2161-0444.1000222

Copyright: ( 2014 Adaszyńska-Skwirzyńska M, et al. This is an open-access article distributed under the terms of the Creative Commons Attribution License which permits unrestricted use, distribution, and reproduction in any medium, provided the original author and source are credited. 


\section{Gas chromatography-mass spectrometry (GC-MS)}

The chemical composition of essential oils was determined by gas chromatography coupled to mass spectrometry (GC/MS) using an Agilent apparatus model 6890 with a chromatographic column HP-5MS of length $30 \mathrm{~m}$, diameter $0.25 \mathrm{~mm}$. Stationary phase film thickness of 0.25 microns and the carrier gas used was helium. Injector temperature was $250^{\circ} \mathrm{C}$. A gradient of temperature was $60^{\circ} \mathrm{C}$ for $3 \mathrm{~min}$., then an increase of $10^{\circ} \mathrm{C} / \mathrm{min}$., to $300^{\circ} \mathrm{C}$. The qualitative analysis was performed based on MS spectra by comparing them with the spectra of the NIST library. The identity of the compounds was confirmed by retention indices with literature data $[28,29]$. Quantitative composition was determined by assuming that the sum of the individual compounds is $100 \%$.

\section{Determination of flavonoids and the sesquiterpene acids}

For further phytochemical studies were used pharmacopoeia procedures [10,30]. Total flavonoids content was expressed as $\mathrm{mg}$ quercetin equivalents / $100 \mathrm{~g}$ dry weight (DW) by spectrophotometer. In order to determine the flavonoids in lavender leafy stems they were extracted with acetone with $25 \% \mathrm{HCl}$, at the reflux. After cooling, the extract was filtered and extracted with ethyl acetate, then the extract obtained was added a $2 \%$ solution of aluminum chloride. The resulting complexes of flavonoids with aluminum are characterized by a yellow color. After 45 minutes, absorbance measurements were performed at $\lambda=425 \mathrm{~nm}$ against the reagent blank solution (without added reagent).

To determine the valerenic and acetoxyvalerenic acids as the sesquiterpene acids in the leafy stem samples were milled then extracted with methanol. The resulting extract was analyzed by HPLC chromatography (Shimadzu chromatograph, SPD-M20A detector, UV-Vis) and chromatographic analysis were carried out in parallel with the internal standard (1,8-dihydroksyantrahinon). The analysis was performed under the following conditions: flow rate $1.5 \mathrm{ml} / \mathrm{min}$, detection wavelength $220 \mathrm{~nm}$, injection volume $20 \mu \mathrm{l}$, mobile phase A: acetonitrile/phosphoric acid in a ratio $20 / 80$, mobile phase $B$ : acetonitrile/ phosphoric acid ratio 80/20.

\section{Antibacterial activity}

The essential oils from the leafy stem were assayed against four bacteria, Staphylococcus aureus PCM 2054/ATCC 25923, Staphylococcus aureus MRSA, Escherichia coli ATCC 25922, Pseudomonas aeruginosa ATCC 9027, Pseudomonas aeruginosa PCR skin and Enterococcus faecalis. Evaluation of antimicrobial activity in vitro of the essential oil was performed with the use of the disc - diffusion method. 18 Hour cultivation of a particular strain of bacteria in liquid medium was diluted with physiological $\mathrm{NaCl}$ solution to a density of $0.5 \mathrm{McF}$ arland. Obtained in this way, a bacterial suspension was applied evenly over the entire plate surface to a solid Mueller-Hinton II (Oxoid), using sterile swab sticks. Paper disks (diameter $6 \mathrm{~mm}$ ) were soaked in $10 \mu \mathrm{l}$ of a particular essential oil (soak time: 1-2 minutes) and were immediately applied symmetrically on the inoculated plate (7 discs/plate). Plates were incubated for $24 \mathrm{~h}$ at $37^{\circ} \mathrm{C} \pm 1^{\circ} \mathrm{C}$. After this time the zones of inhibition were measured (diameter in $\mathrm{mm}$ ). Measurements are made at nine replications. For the positive control were used two antibiotics: gentamicin and amoxicillin.

\section{Results and Discussion}

\section{The chemical composition and contents of flavonoids and the sesquiterpene acids}

Analysis of the main components of essential oils isolated from the leafy stem $s$ of two varieties of lavender (L. angustifolia) is given in Table 1. Table 1 shows the components of the above $1.3 \%$. In the oils tested have been identified forty two compounds of which the main are: borneol (13.8-12.4\%), caryophyllene oxide (8.0-8.7\%), epibicyclosesquiphellandrene (6.8-8.3\%), eucalyptol (3.7-6.2\%), linalool (4.9-5.8\%), geraniol acetate $(4.0-4.1 \%)$ and $\beta$-pinene (3.5$3.6 \%)$. Most of the compounds identified in the oils are examined from monoterpenoids group (48.9-49.1\%). Monoterpenes were from $10.8 \%$ to $14.0 \%$ in $\mathrm{EP}$ and $\mathrm{BR}$, respectively. Besides monoterpenes, monoterpenoids also determined sesquiterpenes (11.7-14.5\%) and sesquiterpenoids $(8.0-8.7 \%)$. Our previously study showed that the primary components of the essential oil from flowers was linalool $18.6 \%$ in BR and $22.4 \%$ in EP [11]. Also, borneol, $\beta$-pinene and eucalyptol were not identified in flowers, caryophyllene oxide and epi-bicyclosesquiphellandrene were present in smaller amounts [11]. Essential oils content were from $0.45 \%$ to $0.60 \%$ in BR and EP, respectively. Research of $L$. coronopofolia Poiert showed that the oils yield obtained from flowering tops, leaves, and from the whole aerial parts were $7.1 \%, 0.6 \%$ and $1.47 \%$, respectively [8]. Study of essential oils from the stems/leaves (L) and flowers (F) of L.stoechas growing wild in Italy showed that the major compound was fenchone, $52.6 \%$ in $\mathrm{L}$ and $66.2 \%$ in $\mathrm{F}$, followed by camphor (13.13\% versus $27.08 \%$, in $\mathrm{L}$ and $\mathrm{F}$, respectively) [9].

The chemical composition of essential oils obtained from the leafy stems, does not compatible with pharmacopoeia and our previously study $[10,11]$. The oil obtained from the leafy stems is characterized by a content of $\alpha$-santalene (2.6-2.3\%), chemical affecting antibacterial activity. This compound was at $1.4 \%$ in flowers oil only in BR [11]. An interesting compounds identified in the oils from the leafy stems is borneol with applications in medicine as an anesthetic Japanese [12] and as a natural insect repellent.

\begin{tabular}{|c|c|c|c|c|}
\hline \multirow{2}{*}{$\begin{array}{l}\text { Compound name } \\
\beta \text {-Pinene }\end{array}$} & \multirow{2}{*}{\begin{tabular}{|c|c|}
$\begin{array}{c}\text { RT } \\
\text { (min) }\end{array}$ \\
6.83
\end{tabular}} & \multirow{2}{*}{$\begin{array}{l}\mathbf{R I}^{*} \\
975\end{array}$} & \multicolumn{2}{|c|}{$\begin{array}{l}\text { Percentage (\%) Blue } \\
\text { River Ellegance Purple }\end{array}$} \\
\hline & & & 3.54 & 3.62 \\
\hline o-Cymene & 8.11 & 1021 & 1.53 & 1.21 \\
\hline p-Cymene & 8.19 & 1024 & 2.94 & 2.24 \\
\hline Limonene & 8.30 & 1028 & 2.25 & 0.83 \\
\hline Eucalyptol & 8.36 & 1031 & 6.19 & 3.66 \\
\hline trans Linalol oxide & 9.58 & 1072 & 1.65 & 1.90 \\
\hline cis Linalol oxide & 10.04 & 1077 & 1.48 & 1.64 \\
\hline Linalool & 10.41 & 1100 & 4.90 & 5.76 \\
\hline Pinocarveol & 11.55 & 1140 & - & 2.31 \\
\hline Camphor & 11.68 & 1144 & 2.58 & 2.52 \\
\hline Borneol & 12.38 & 1168 & 13.84 & 12.43 \\
\hline p-Cymen-8-ol & 12.84 & 1184 & 1.83 & 2.26 \\
\hline Crypton & 12.94 & 1187 & 3.66 & - \\
\hline Myrtenal & 13.21 & 1196 & 2.23 & 1.44 \\
\hline Myrtenol & 13.24 & 1197 & - & 1.43 \\
\hline Eucarvone & 13.56 & 1209 & 2.02 & - \\
\hline Borneol acetate & 14.08 & 1228 & 1.05 & 0.74 \\
\hline Geraniol & 14.84 & 1255 & 0.83 & 1.28 \\
\hline Lavandulol acetate & 15.81 & 1289 & 1.37 & - \\
\hline Geraniol acetate & 18.28 & 1383 & 4.01 & 4.11 \\
\hline a-Santalene & 19.23 & 1420 & 2.63 & 2.35 \\
\hline$\delta$-Cadinene & 21.59 & 1516 & 2.00 & 2.84 \\
\hline Caryophyllene oxide & 23.26 & 1586 & 7.98 & 8.68 \\
\hline Epibicyclosesquiphellandrene & 24.59 & 1645 & 6.82 & 8.26 \\
\hline TOTAL IDENTIFIED [\%] & & & 87.96 & 84.31 \\
\hline
\end{tabular}

*Retention index on a HP-5 MS column. Constituent identification based on RI\&MS matching $[28,29]$, and NIST database.

Table 1: The comparison of the constituents of the leafy stems of lavender (Lavandula angustifolia) varieties. 
Total flavonoids content in two plants is presented in Table 2. Flavonoids content was similar, from 341 to 352 quercetin equivalents $\mathrm{mg} / 100 \mathrm{~g}$ in EP and BR, respectively. This is significantly higher than the flavonoids content compared to lavender flowers at $86 \mathrm{mg} / 100 \mathrm{~g}$, as a raw pharmacopoeia [10] and our results (Table 2). In lavender leaves found flavonoids only $30 \mathrm{mg} / 100 \mathrm{~g}$ [13]. Similar results to our study obtained Kyunga at al. [14], and Bouayed et al. [15]. A literature review showed that the anxiolytic and sedative effect may also be responsible flavonoids [16-17].

Based on the data presented in Table 2, it was found that the leafy stems was valerenic acid at $1.08 \mathrm{mg} / 100 \mathrm{~g}$ in $\mathrm{BR}$, and the least 0.81 $\mathrm{mg} / 100 \mathrm{~g}$ in EP. Significant differences between comparable varieties of lavender in this experiment, was found in the case of acetoxyvalerenic acid. The leafy stems of BR characterized by content of acetoxyvalerenic acid at 45.9 were compared to EP at $14.0 \mathrm{mg} / 100 \mathrm{~g}$. This result showed smaller sesquiterpene acids content in comparing to valerian garden heliotrope (Valeriana officinalis) [18].

\section{Antibacterial activity}

Table 3 shows the zones of inhibition on S. aureus, P. aeruginosa, Escherchin coli and Enteroccus faecalis bacteria as a result of the influence of the essential oils from BR and EP varieties. Results showed the highest increase of $S$. aureus bacteria was inhibited by the activity of the essential oils from both varieties. Medium zones of inhibition were as follows on: S. aureus (reference strain PCM 2054/ATCC 25923) $21.8 \mathrm{~mm}$ versus $24.0 \mathrm{~mm}$, through BR and EP, respectively. The zones of inhibition on S. aureus (MRSA) were as follows on: $25 \mathrm{~mm}$ versus 26 $\mathrm{mm}$, through BR and EP, respectively. Less effect noticed for Escherichia

\begin{tabular}{|c|c|c|c|c|}
\hline \multirow{2}{*}{$\begin{array}{c}\text { Variety of } \\
\text { lavender }\end{array}$} & \multicolumn{2}{|c|}{ Sesqiterpene acids $(\mathrm{mg} / 100 \mathrm{~g})$} & \multicolumn{2}{|c|}{$\begin{array}{c}\text { Total flavonoids content } \\
\text { (mg/100 g) }\end{array}$} \\
\hline Blue River & 1.08 & 45.9 & $352 \pm 131$ & $91 \pm 34$ \\
\hline $\begin{array}{c}\text { Ellegance } \\
\text { Purple }\end{array}$ & 0.81 & 14.0 & $341 \pm 127$ & $86 \pm 32$ \\
\hline
\end{tabular}

*VA - Valerenic acid, ${ }^{* *} A A-$ Acetoxyvalerenic acid

Table 2: Assay phytosubstances in the leafy stems and flowers of of lavender (Lavandula angustifolia) varieties.

\begin{tabular}{|c|c|c|c|c|}
\hline \multirow{2}{*}{ Name of bacteria } & \multirow{2}{*}{ Description } & \multicolumn{2}{|c|}{$\begin{array}{l}\text { Average of zone } \\
\text { inhibition }(\mathrm{mm}) \pm S D\end{array}$} & \multirow{2}{*}{$\begin{array}{l}\text { Degree } \\
\text { of inhibition }\end{array}$} \\
\hline & & Blue River & $\begin{array}{l}\text { Ellegance } \\
\text { Purple }\end{array}$ & \\
\hline $\begin{array}{l}\text { Staphylococcus } \\
\text { aureus }\end{array}$ & ATCC $25923^{*}$ & $21.8 \pm 0.4$ & $24.0 \pm 0.2$ & $\begin{array}{l}\text { BR +++ } \\
\text { EP +++ }\end{array}$ \\
\hline $\begin{array}{l}\text { Staphylococcus } \\
\text { aureus }\end{array}$ & MRSA ** & $25.0 \pm 0.3$ & $26.0 \pm 0.6$ & $\begin{array}{l}+++ \\
+++\end{array}$ \\
\hline $\begin{array}{l}\text { Pseudomonas } \\
\text { aeruginosa }\end{array}$ & ATCC 9027 & $10.1 \pm 0.2$ & $8.0 \pm 0.2$ & $\begin{array}{l}+/- \\
+/-\end{array}$ \\
\hline $\begin{array}{l}\text { Pseudomonas } \\
\text { aeruginosa }\end{array}$ & PCR skin *** & $8.9 \pm 0.5$ & NZ & $+/-$ \\
\hline Escherichia coli & ATCC 25922 & $12.5 \pm 0.3$ & $13.2 \pm 0.4$ & $\begin{array}{l}+ \\
+\end{array}$ \\
\hline $\begin{array}{l}\text { Enterococcus } \\
\text { faecalis }\end{array}$ & & $9.0 \pm 0.2$ & $10.5 \pm 0.3$ & $\begin{array}{l}+/- \\
+\end{array}$ \\
\hline
\end{tabular}

* The S. aureus strain ATCC 25923 is a strain to control antibiograms,

** MRSA - Methicillin Resistant Staphylococcus aureus is a multi-antibiotic resistance strain,

*** PCR - Polymerase Chain Reaction ; NZ= No zone inhibition of growth

Relative degree of inhibition of bacterial growth: $\leq 6 \mathrm{~mm}(-)$ no zone inhibition of growth; 7-9 mm (+/-);

10-14 mm (+); 15-18 (++); $\geq 19 \mathrm{~mm}(+++)$

Table 3: Zones of inhibition of bacterial growth by essential oils from the leafy stems of two lavender (Lavandula angustifolia) varieties and relative degree of inhibition of bacterial growth. coli (reference strain ATCC 25922), $12.5 \mathrm{~mm} \mathrm{BR}$ versus $13.2 \mathrm{~mm} \mathrm{EP}$, respectively. EP or BR had poor or no effect on inhibition other bacteria tested Enterococcus faecalis (ATCC) and P. aeruginosa (ATCC 9027 and PCR skin) [30-32].

The differences in their antibacterial activity are due to the difference in components of particular varieties which may be connected with their properties and bioactivity. Soković et al. proved that the zone of inhibition on S. aureus bacterium of the oil from flowers L. angustifolia was stronger than on $P$. aeruginosa [19]. Serban et al. studied the activity of lavender oil (L. hybrida), whose primary components were $\beta$-linalool and linalyl acetate [20]. Dorman and Deans studied the activity of linalool and limonene extracted from lavender oil against twenty five bacteria [21]. The studies proved the linalool of inhibition on $S$. aureus. Chemical compositions and inhibitory effects of essential oils Spanish lavender (L. stoechas subsp. stoechas L.) on Escherichia coli O157:H7, Listeria monocytogenes, Salmonella typhimurium, and S.aureus showed exhibited a very strong antibacterial activity against the tested bacteria [22]. Similar results obtained for Lavandula stoechas L. growing wild in Turkey [23], and Tunisia [24]. The antibacterial activity of oils from L. angustifolia was tested against clinical bacterial strains of Staphylococcus, Enterococcus, Escherichia and Pseudomonas genera [25]. They found that lavender oil has been less activity against clinical strains of Staphylococcus, Enterococcus and Escherichia genus in compared to thyme oil. The worst results have been observed against all strains of Pseudomonas aeruginosa [25]. Essential oil extracted from flower of lavender ( $L$. angustifolia) was tested for their antibacterial activities against gram-positive and gram-negative bacteria. Both gram-positive and gram-negative bacteria were found susceptible to the studied flower essential oil [26]. The other research showed result of the antimicrobial activity of $L$. angustifolia essential oil in combination with 45 other oils to establish possible interactive properties [27]. The in vitro antimicrobial activity of $L$. angustifolia essential oil in combination with other aroma-therapeutic oils showed stronger effect [27]. From the comparison antibacterial activities of essential oils from the stems/leaves in this study with flowers of L. angustifolia growing in Poland [11] showed stronger effect in the leafy stems [28-32].

\section{Conclusion}

The search for new possibilities of use of natural organic waste in recent years. The broad spectrum of biological activity of the essential oil and extracts derived from lavender flowers, leads to the study of properties and chemical composition of leafy stems. Research has shown that the leafy stems of lavender can be characterized by many advantageous biological properties due to its content of biologically active substances such as essential oils and flavonoids with antimicrobial properties or sesquiterpene acids for sedative action. We need additional laboratory and clinical studies proving the effect in animals and humans.

\section{Acknowledgements}

This study was supported by the Polish Ministry of Science and High Education under grant No. N N310 729040.

\section{References}

1. Lis-Balchin M. Lavender (2002) The genus Lavandula, London: Taylor \& Francis.

1. Cavanagh HM, Wilkinson JM (2002) Biological activities of lavender essential oil. Phytother Res 16: 301-308.

2. Moon T, Cavanagh HMA, Wilkinson JM (2006) Antibacterial activity of essential oils, hydrosols and plant extracts from Australian grown Lavandula spp. Int $J$ Aromath 16: 9-14.

3. Sayorwan W, Siripornpanich V, Piriyapunyaporn T, Hongratanaworakit $T$ 
Kotchabhakdi N, et al. (2012) The effects of lavender oil inhalation on emotional states, autonomic nervous system, and brain electrical activity. J Med Assoc Thai 95: 598-606.

4. Woronuk G, Demissie Z, Rheault M, Mahmoud S (2011) Biosynthesis and therapeutic properties of Lavandula essential oil constituents. Planta Med 77 : 7-15.

5. Sasannejad P, Saeedi M, Shoeibi A, Gorji A, Abbasi M, et al. (2012) Lavender essential oil in the treatment of migraine headache: a placebo-controlled clinical trial. Eur Neurol 67: 288-291.

6. Nikfarjam M, Parvin N2, Assarzadegan N3, Asghari S4 (2013) The Effects of Lavandula Angustifolia Mill Infusion on Depression in Patients Using Citalopram: A comparison Study. Iran Red Crescent Med J 15: 734-739.

7. Aburjai T, Hudiab M, Cavrini V (2005) Chemical composition of the essential oil from different aerial parts of Lavender (Lavandula coronopofolia Poiert) (Lamiaceae) grown in Jordan. Journal of Essential Oil Research 17: 49-51.

8. Angioni A, Barra A, Coroneo V, Dessi S, Cabras P (2006) Chemical composition, seasonal variability, and antifungal activity of Lavandula stoechas L. ssp. stoechas essential oils from stem/leaves and flowers. J Agric Food Chem 54: 4364-4370.

9. Campana RA, Namur JA, Takata CS, de Araujo PS, Bueno da Costa MH (2004) lonic interfaces and diphtheria toxoid interactions. Protein Expr Purif 33: $161-165$

10. Adaszynska M, Swarcewicz M, Dzieciol, M, Dobrowolska A (2013) Comparison of chemical composition and antibacterial activity of lavender varieties from Poland. Nat Prod Res 27: 1497-1501.

11. Granger RE, Campbell EL, Johnston GA (2005) (+)- And (-)-borneol: efficacious positive modulators of GABA action at human recombinant alpha1beta2gamma2L GABA(A) receptors. Biochem Pharmacol 69: 11011111.

12. Miliauskas G, Venskutonis PR, van Beek T (2004) Screening of radical scavenging activity of some medicinal and aromatic plant extracts. Food Chem 85: 231-237.

13. Kyung MO, Choong HL, Hjungjae L, BoKyung M, Chang YL (2008) Relative antioxidant and cytoprotective activities of common herbs. Food Chem 106: 929-936.

14. Bouayed J, Piri K, Rammal H, Dicko A, Desor F, et al. (2007) Comparative evaluation of the antioxidant potential of same Iranian medicinal plants. Food Chem 104: 364-368.

15. Nijveldt RJ, van Nood E, van Hoorn DE, Boelens PG, van Norren K, et al. (2001) Flavonoids: a review of probable mechanisms of action and potential applications. Am J Clin Nutr 74: 418-425.

16. Sandhar HK, Kumar B, Prasher S, Tiwari P, Salhan M (2011) A review of phytochemistry and pharmacology of flavonoids. Internat Pharm Sci 1: 25-41.
17. Blumenthal M, Goldberg A, Brinckann J (2012) Herbal Medicine, Expanded Commission E Monographs.

18. Sokovic M, Glamoclija J, Marin PD, Brikic D, van Griensven LJLD (2010) Antibacterial effects of the essential oils of commonly consumed medicinal herbs using an in vitro model. Molecules 15: 7532-7546.

19. Serban ES, lonescu M, Matinca D, Maier CS (2011) Screening of the antibacterial and antifungal activity of eight volatile essential oils. Farmacia 3 : 440-446.

20. Dorman HJ, Deans SG (2000) Antimicrobial agents from plants: antibacterial activity of plant volatile oils. J Appl Microbiol 88: 308-316.

21. Dadalioglu I, Evrendilek GA (2004) Chemical compositions and antibacteria effects of essential oils of Turkish oregano (Origanum minutiflorum), Bay laurel (Laurus nobilis), Spanish lavender (Lavandula stoechas L.), and fennel (Foeniculum vulgare) on common foodborne pathogens. J Agric Food Chem 52: 8255-8260.

22. Kirmizibekmez H, Demirci B, Yesilada E, Baser KH, Demirci F (2009) Chemical composition and antimicrobial activity of the essential oils of Lavandula stoechas L. ssp. stoechas growing wild in Turkey. Nat Prod Commun 4: 1001 1006.

23. Bouzouita N, Kachouri F, Hamdi M, Chaabouni MM, Aissa RBen, et al. (2005) Volatile constituents and antimicrobial activity of Lavandula stoechas L. oil from Tunisia. J Essential Oil Research 17: 584-586.

24. Sienkiewicz M, Lysakowska M, Ciecwierz J, Denys P, Kowalczyk E (2011) Antibacterial activity of thyme and lavender essential oils. Med Chem 7: 674-689.

25. Lodhia MH, Bhatt KR, Thaker VS (2009) Antibacterial activity of essential oils from palmarosa, evening primrose, lavender and tuberose. Indian J Pharm Sci 71: $134-136$.

26. de Rapper S, Kamatou G, Viljoen A van Vuuren S (2013) The In Vitro Antimicrobial Activity of Lavandula angustifolia Essential Oil in Combination with Other Aroma-Therapeutic Oils. Evid Based Complement Alternat Med 2013: 852049

27. Babushok VI, Linstrom PJ, Zenkevic IG (2011) Retention indices for frequently reported compounds of plant essential oils. J Phys Chem Ref Data 40: 431011-431046.

28. Adams RP (2007) Identification of Essential Oil Components by Gas Chromatography /Mass Spectrometry, 4th Ed. Allured Publishing, Caro Stream, Illinois.

29. Polish Pharmacopoaia VI (2002) Warsaw, Poland

30. Cavanagh HMA, Wilkinson JM (2005) Lavender essentials oil: a review. Australian Infection Control 10: 35-37.

31. Sabara D, Kunicka-Styczynska A (2009) Lavender oil- flavouring or active cosmetics ingredient? Food Chem Biotech 73: 33-41. 